\title{
Работники старших возрастов в российском неформальном секторе: масштаб, динамика и структура занятости ${ }^{1}$
}

\author{
А.А. ЗУДИНА*
}

\begin{abstract}
*Анна Алексеевна Зудина - кандидат социологических наук, научный сотрудник, Центр трудовых исследований, Национальный исследовательский университет «Высшая школа экономики». Адрес: 101000, Москва, ул. Мясницкая, д. 20. E-mail: azudina@hse.ru
\end{abstract}

Цитирование: Зудина А.А. (2021) Работники старших возрастов в российском неформальном секторе: масштаб, динамика и структура занятости // Мир России. Т. 30. № 2. C. 72-97. DOI: 10.17323/1811-038X-2021-30-2-72-97

Во многих странах неформальная занятость и занятость в неформальном секторе традиционно рассматриваются в качестве ключевых разновидностей уязвимого и незашищенного труда. Они по определению сопряжень с отсутствием официильного трудового договора или контракта и поэтому представляют собой один из важнейших вызовов для современной пенсионной системы и системь социальной защиты. Наибольшие риски вовлеченности в неформальную занятость несут те представители рынка труда, которые по тем или иным причинам сталкиваются с ограничениями в возможностях трудоустройства на формальных рабочих местах. Среди них - занятые старших возрастов. В настоящей работе на данных Обследования рабочей силы (ОРС) Росстата за 2000, 2005, 2010 и 2015 г2. впервые подробно рассмотрены масштаб, динамика и структура занятости в неформальном секторе работников предпенсионного и пенсионного возраста, а также долгосрочные тенденции социально-демографических и профессиональноотраслевых характеристик, которые ранее не являлись предметом иеленаправленного изучения. Полученные результаты свидетельствуют о том, что к 2015 г. на российском рынке труда в неформальном секторе было занято более 3 млн человек старше 50 лет, при этом неформальность получила наибольщее распространение среди работников преклонного возраста (старше 65 лет). Одновременно наблюдалась тенденция к возрастаюшей деформализации занятости работников 50-54 лет, которая может объясняться ухудшением перспектив поиска работы и карьерного продвижения для занятых в ранних предпенсионных возрастах. Важнейшей характеристикой российской неформальной

\footnotetext{
1 Исследование осуществлено в рамках Программы фундаментальных исследований НИУ ВШЭ. Автор выражает признательность за ценные замечания и комментарии В.Е. Гимпельсону.
} 
занятости является возрастающее сближение образовательной и профессиональноотраслевой структуры работников разных возрастов. Основные риски неформальной занятости среди работников старше 60 лет перемещзаются от наиболее низких уровней образования (основное общее, начальное или без образования) к среднему профессиональному и среднему (полному) общему образованию. Именно они связань с наибольшими рисками неформальности и в основных трудоспособных возрастах, и среди 50-59-летних неформальных работников. Помимо этого, работники старших возрастов трудятся в тех же отраслях и профессиях неформального сектора, что и более молодые его представители, что демонстрирует универсальный характер спроса на труд в неформальном секторе, в котором находят работу как молодые, так и пожилье работники. Отмеченное сближение структуры занятости в неформальном секторе работников разных возрастов, сочетающееся с будущим вступлением в старшие возраста более многочисленных когорт и возрастающей деформализацией занятости 50-59-летних, может привести к дальнейшей экспансии неформальности на российском рынке труда.

Ключевые слова: пожилые работники, неформальный сектор, рынок труда, выход на пенсию, Россия, обследование рабочей силы

\section{Введение}

Неформальная занятость и занятость в неформальном секторе (НФС) являются основными разновидностями уязвимого и незащищенного труда. Они не предполагают официального трудового договора или контракта, что приводит к ограничению возможностей формирования обязательных пенсионных накоплений и доступа к социальной защите. Помимо этого, неформальный характер трудовых отношений зачастую сопряжен с меньшим уровнем заработной платы и доходов, а также с занятостью на низкопроизводительных рабочих местах. Наибольшие риски неформальной занятости характерны для работников, по тем или иным причинам испытывающих сложности с официальным трудоустройством. К ним традиционно относят женщин, молодежь, а также представителей старших возрастов [OECD 2008; ILO 2014]. Характеристики человеческого капитала и здоровье последних могут уже не соответствовать требованиям формальных рабочих мест, ввиду чего работники предпенсионного и пенсионного возраста вынуждены искать себе работу в неформальном сегменте рынка труда. Для России изучение особенностей неформальной занятости работников старших возрастов имеет особую актуальность. Неформальные трудовые отношения стали активно развиваться в период перехода к рыночной системе, однако, несмотря на произошедшие изменения, масштаб неформальности по-прежнему значителен. Согласно данным Росстата, в 2017-2018 гг. российский неформальный сектор аккумулировал около $20 \%$ всех занятых, что составляло более 14 млн чел. Продолжительная история вовлеченности российской рабочей силы в неформальную трудовую деятельность уже сейчас приводит к возникновению так называемых серых пенсийㄹ, т. е. ситуаций, при которых страхового стажа работников и официальных отчислений рабо-

2 Малышева Е., Копалкина Е. (2017) После серой зарплаты пришла серая пенсия // Gazeta.ru. 31 марта 2017 // https://www.gazeta.ru/business/2017/03/31/10605221.shtml 
тодателей, сделанных в 1990-е гг., оказывается недостаточно для формирования пенсионных накоплений. В подобном положении оказываются те, кто в течение своей трудовой жизни был занят неофициально или же большую часть своей заработной платы получал в конвертах. Старение населения и возрастающая нагрузка по отчислениям в социальные фонды на официально занятых из более молодых возрастных когорт также определяют важность изучения указанной темы.

Целью настоящей работы является анализ долгосрочных тенденций неформальной занятости российских работников старших возрастов и изменений в ее структуре, которое ранее не было предметом специализированного изучения. На данных Обследования рабочей силы (ОРС) Росстата за 2000, 2005, 2010 и 2015 гг. $^{3}$ впервые рассматриваются масштаб, динамика и структура занятости в неформальном секторе работников предпенсионного и пенсионного возраста, социально-демографические характеристики неформальных работников, а также профессиональные и отраслевые особенности занимаемых ими рабочих мест.

\section{Основные подходы к определению неформальности на рынке труда и особенности неформальной занятости работников старших возрастов в зарубежных странах}

Эмпирический анализ основывается на микроданных Обследования рабочей силы (ОРС; до 2016 г. - Обследование населения по проблемам занятости, или ОНПЗ). Оно представляет собой ежеквартальное, а с сентября 2009 г. - ежемесячное выборочное обследование домохозяйств, проводимое во всех субъектах Российской Федерации в соответствии с методологией Международной организации труда (MOT). Годовая выборка ОРС при ежеквартальном сборе данных (т. е. с 1999 г. до середины 2009 г.) составляла около 270 тыс. чел., а с переходом к ежемесячному опросу в сентябре 2009 г. ее объем увеличился в три раза (около 800 тыс. чел.). В настоящей работе анализировались годовые данные за 2000, 2005, 2010 и 2015 гг., учитывалась только основная работа респондента, под занятыми предпенсионного и пенсионного возраста подразумевались работники в возрасте 50-72 лет.

Использование данных ОРС предполагает опору на принятое Росстатом производственное определение неформальности на рынке труда, связывающее ее с характеристиками предприятий и подразумевающее выделение неформального сектора (см. [Понятия и определения 2015]). Под предприятиями неформального сектора понимается «совокупность производственных единиц, составляющих часть сектора домашних хозяйств, или некорпоративных предприятий, принадлежащих домашним хозяйствам, которые осуществляют производство товаров

\footnotetext{
3 Данные за более поздние доступные годы не рассматривались, т. к. с 2016 г. ОРС перешло к новым классификаторам занятий (профессий) (ОКЗ), а также видов деятельности (отраслей) (ОКВЭД), что делает анализ динамики структуры занятости в неформальном секторе по указанным параметрам не полностью сопоставимым. Изменения в структуре российской занятости в 2016-2018 гг., согласно статистике рынка труда, были минимальными, и потому не могли повлиять на выводы настоящей работы, основанные на изучении долгосрочных тенденций. Постепенное повышение пенсионного возраста, в соответствии с Феральным законом №350-Ф3 от 3 октября 2018 г., началось только в 2019 г., и его влияние на изменение поведения работников, по очевидным причинам, проявится позднее. С учетом этого данные за 2015 г. остаются актуальными и релевантными рассматриваемой теме.
} 
и услуг для реализации на рынке и не являются самостоятельными юридическими единицами, созданными отдельно от домашнего хозяйства или его членов, которым они принадлежат» ${ }^{4}$. Основным критерием выделения таких предприятий является отсутствие государственной регистрации бизнеса в качестве юридического лица, т. е. их неинкорпорированный характер. Тем самым при использовании производственного определения из анализа исключается занятость на предприятиях формального сектора (ФС), осуществляемая без оформления договора или контракта. Важно подчеркнуть, что неформально занятые по применяемому в ОРС производственному определению с высокой вероятностью могут оказаться неформальными и в случае применения к ним так называемого легалистского определения. Рамки неформальной занятости, согласно последнему, определяются в зависимости от степени соблюдения разнообразных установленных правил и законодательных норм на рабочих местах. Занятость вне корпоративного сектора, зачастую осуществляющаяся на низкоквалифицированных рабочих местах с невысокой производительностью, с точки зрения легалистского подхода либо не регулируется вообще, либо регулируется с помощью упрощенных процедур и правил. Последние снижают уровень социальной защищенности работников ниже стандартов трудового законодательства, принятых для занятых на формальных предприятиях, и поэтому выделяемые при помощи производственного определения виды занятости в неформальном секторе зачастую являются и более уязвимыми по легалистскому определению неформальности.

В рамках ОРС фиксируются несколько категорий работников, занятых вне корпоративного сектора:

1) занятые по найму у физических лиц, индивидуальных предпринимателей;

2) занятые предпринимательской деятельностью без образования юридического лица;

3) занятые на индивидуальной основе (самозанятые);

4) занятые в домашнем хозяйстве по производству продукции, предназначенной для реализации;

5) занятые в фермерском хозяйстве в случаях, если регистрация или оформление документов отсутствует либо с регистрацией в качестве индивидуального предпринимателя.

Категории 2-5 представляют собой различные типы самозанятости, в то время как категория 1 - занятых по найму.

Данные ОРС также позволяют выделить категорию занятых на предприятиях формального сектора без оформления какого-либо трудового контракта, т. е. на основе устной договоренности. Эта группа работников не участвует в формировании показателя занятости в неформальном секторе, однако является одной из разновидностей неформальной занятости. Во все рассматриваемые годы наблюдения, согласно данным ОРС, доля этой категории составляла менее $1 \%$ от численности занятых разных возрастов (Приложение, таблица Б), поэтому в настоящей работе под неформальными работниками понимались занятые в неформальном секторе.

Согласно оценкам МОТ, по всему миру около 78\% работников старше 65 лет заняты неформально [ILO 2018]. Наибольшие значения характерны для

4 См. [Методологическое руководство 2002], которое базируется на рекомендациях 15-й Международной конференции статистиков труда. 
африканских стран и стран Азиатско-Тихоокеанского региона (более $85 \%$ ), а наименьшие - для Европы и Центральной Азии (около 40\%). По сравнению с молодежью среди работников старших возрастов риски неформальной занятости всегда оказываются выше вне зависимости от региона и уровня социально-экономического развития страны [ILO 2018]. Вероятность перемещения работников из формального сегмента рынка труда в неформальный с возрастом увеличивается, при этом одним из факторов является конкуренция за рабочие места с более молодыми работниками [Alvarez, Potes, Merchán 2016], которым работодатели отдают предпочтение [Perron 2018]. Переходы в формальную занятость из неформальной среди работников старших возрастов также совершаются значимо реже, чем среди молодых [McCaig, Pavcnik 2015].

Для части работников старших возрастов перемещение в неформальную занятость и неформальный сектор может быть вполне добровольным, что подтверждает существующую концепцию о различии в предпочтениях формальной/неформальной занятости в течение жизненного цикла [Maloney 1999]. Накопив в рамках формальной наемной занятости достаточные финансовые ресурсы, практический опыт, а также профессиональные знания и навыки, работники стремятся открыть собственное дело [Perry et al. 2007] и переходят из формального сектора в различные варианты самозанятости и индивидуального предпринимательства, по производственному определению относящиеся к неформальному сектору [Sahoo, Neog 2015]. Например, в странах Латинской Америки формальная занятость доминирует среди работников основных трудоспособных возрастов, в то время как самозанятость является одним из наиболее предпочтительных типов трудовой деятельности среди работников старше 50 лет в Мексике и старше 60 лет в Аргентине и Бразилии. Выбор в пользу самозанятости определяется такими преимуществами, как гибкий график, сокращенный рабочий день и относительно более высокие заработки [Perry et al. 2007]; основными отраслями самозанятости при этом становятся торговля и сельское хозяйство [Murrugarra 2011].

Однако во многих случаях отсутствие официальной регистрации трудовых отношений связано со значительной уязвимостью занятости работников старших возрастов и имеет вынужденный характер. Потенциальные риски снижения производительности труда и качества различных составляющих человеческого капитала у работников предпенсионного и пенсионного возраста могут приводить к дискриминации на рынке труда [Perron 2018] и более длительному пребыванию в состоянии безработицы [Farber 2004]. Ухудшение состояния здоровья, устаревание полученного профессионального образования, трудности с адаптацией к технологическим изменениям в организации труда, а также сокращенный период будущей отдачи от дополнительного обучения [Heywood, Siebert 2009] могут перевешивать в глазах работодателя преимущества занятости работников старших возрастов, связанные со значительным общим и специфическим стажем, а также сформированной лояльностью организации. Формальная занятость работников старших возрастов приносит дополнительные издержки для работодателя, связанные с возрастающими расходами на медицинское обслуживание, необходимостью обеспечения более гибкого рабочего графика или сокращением количества рабочих часов, большим выходным пособием в случае увольнения, а также возможным несоответствием установленной заработной платы реальной производительности труда [OECD 2008]. Жесткое законодательство о защите занятости работников с постоян- 
ным контрактом также увеличивает издержки найма работников старших возрастов [Вишневская 2017; Gatti et al. 2014]. Своеобразным вариантом законодательства о защите занятости являются и антидискриминационные законодательные акты о защите работников старших возрастов, которые в большей степени защищают права тех, кто уже имеет работу, увеличивая не только издержки их увольнения для работодателя, но и затраты по найму новых работников старших возрастов [Heywood, Siebert 2009; Lahey 2010]. Перечисленные факторы, определяющие спрос на труд пожилых работников, приводят к тому, что работодатели стараются вытеснить их в область неформальной занятости. Это может осуществляться либо путем найма без заключения трудового договора или контракта, либо путем перемещения сотрудников внутри фирмы на неформальные рабочие места, не предполагающие полноценных отчислений в социальные фонды (зарплата в конвертах), либо путем перехода работников в низкоквалифицированную самозанятость в результате невозможности устроиться на наемную работу в формальный сектор.

В свою очередь для беднейших слоев населения издержки, связанные с необходимыми отчислениями в систему социального страхования, могут также оказаться чрезмерными, и потому они сами будут избегать формальных рабочих мест [Mikkonen-Jeanneret, Rayapova, Yefimov 2011]. Другим фактором на стороне предложения труда выступают особенности системы социальной поддержки, прежде всего существующей системы формирования пенсионных накоплений, и официальный возраст выхода на пенсию. Если стимулы к накоплению страхового стажа в рамках формальной занятости являются слабыми (к примеру, когда продолжительный страховой стаж не приносит значительных преимуществ и размер будущей пенсии невелик), неформальная занятость становится более привлекательной альтернативой работе с официальным оформлением.

Перечисленные причины приводят к тому, что для представителей старших возрастов неформальная занятость, в особенности низкоквалифицированная самозанятость [Oude Mulders, Wadensjö 2015], может являться единственным доступным способом получения трудового дохода и возможностью интеграции в трудовую жизнь [OECD 2008; Kelly 2005; Jütting, Parlevliet, Xenogiani 2008; Alvarez, Potes, Merchán 2016]. При отсутствии альтернативных источников дохода вовлеченность в данный тип занятости в старших возрастах значительно возрастает [Tondini, Ardington, Woolard 2017].

Неформальные работники старших возрастов, проработавшие без официального оформления продолжительное время, после выхода на пенсию также будут вынуждены оставаться занятыми. Существующие государственные пенсионные программы, предполагающие уплату пенсионных взносов и накопление страхового стажа, сконструированы для учета интересов работников, имеющих официальный контракт с организацией при условии полного соблюдения работодателем всех обязательств. Поэтому неформальные работники, как правило, практически полностью исключены из государственной системы формирования обязательных пенсионных накоплений [Stuart, Samman, Hunt 2018]. В низкодоходных странах ситуация дополнительно усугубляется ограниченностью возможностей для материальной поддержки населения со стороны системы социальной защиты [MikkonenJeanneret, Rayapova, Yefimov 2011].

В отличие от многих зарубежных стран сложившаяся в России система пенсионного страхования не может рассматриваться в качестве однозначного 
преимущества формальной занятости. Минимальный страховой стаж, необходимый для начисления пенсий, на протяжении 2000-х гг. составлял пять лет, а каждый дополнительный год стажа давал небольшую прибавку к пенсии, что было слабым стимулом для занятости в формальном секторе [Лукьянова 2012; Синявская, Бирюкова 2018]. Небольшой размер пенсий также способствовал вовлечению в категорию неформальных работников тех, кто, заработав стаж в формальном секторе, после выхода на пенсию стремился получить дополнительный доход, не предполагающий отчислений в социальные фонды [OECD 2008; Perry et al. 2007] (например, подобная ситуация наблюдается также в Бразилии [The World Bank 2009]). Согласно авторским расчетам на данных ОРС, в России в 2000-2015 гг. доля получателей пенсии по возрасту, выслуге лет или на льготных условиях среди занятого в неформальном секторе населения старше трудоспособного возраста (55 лет для женщин и 60 лет для мужчин) в среднем составляла более 95\%.

\section{Масштаб и динамика занятости работников старших возрастов в российском неформальном секторе}

На рисунке 1 представлены структура численности занятых в неформальном секторе в России и ее динамика в 2000-2015 гг. по возрастным группам. На фоне общего увеличения занятых в НФС с 8 до 13,5 млн чел. можно выделить отчетливую тенденцию к возрастанию численности работников в возрасте 50-59 лет с 708 тыс. чел. в 2000 г. до 2,5 млн чел. в 2015 г. В процентном отношении это означает изменение их доли в общей структуре неформальности с 9 до 19\%. Показатели прироста доли данной возрастной категории в структуре занятости в НФС также превышали аналогичные показатели по остальным возрастам, варьируясь от 2,7 до 4,5 п. п. (Приложение, таблица A).

В свою очередь работники самой старшей возрастной группы (60-72 лет) составляли более 1 млн чел. в 2000 г. (или около $13 \%$ всех занятых в НФС), к 2010 г. их численность сократилась почти вдвое, однако затем вновь стала расти: к 2015 г. к ней относилось около 765 тыс. чел. (или чуть менее $6 \%$ всех работников НФС). Тем не менее, несмотря на описанную динамику, доминирующее положение в структуре НФС по-прежнему занимали работники основного трудоспособного возраста (20-49 лет). На каждую из входящих в него возрастных категорий приходилось 2-3 млн чел. Наименее многочисленными оставались 15-19-летние, насчитывавшие к 2015 г. чуть более 200 тыс. чел. (1,5\% всех работников НФС) Это соответствует общей тенденции современных рынков труда, согласно которой большая часть молодежи в данных возрастах продолжает получать образование, и потому ее экономическая активность, как правило, невелика.

В таблище Б Приложения представлены уровни занятости в НФС и ФС отдельно по каждой возрастной категории работников. В рассматриваемый период среди работников основных трудоспособных возрастов преобладала формальная занятость: в каждой из четырех временных точек, отобранных для анализа, соот-

\footnotetext{
5 Для обеспечения сопоставимого сравнения структуры занятости в НФС между представителями различных возрастных групп данная категория была исключена из дальнейшего анализа.
} 
ветствующая доля составляла более $80 \%$ и последовательно увеличивалась с возрастом, достигая максимальных значений среди 50-59-летних. В противоположность этому занятость в НФС в наибольшей степени была распространена среди работников старше 60 лет: в самой старшей группе (60-72 лет) доля занятых в ФС варьировалась от 68\% в 2000 г. до 79\% в 2015 г. Указанные результаты согласуются с предшествующими исследованиями по России [Сонина, Колоснищьна 2015].

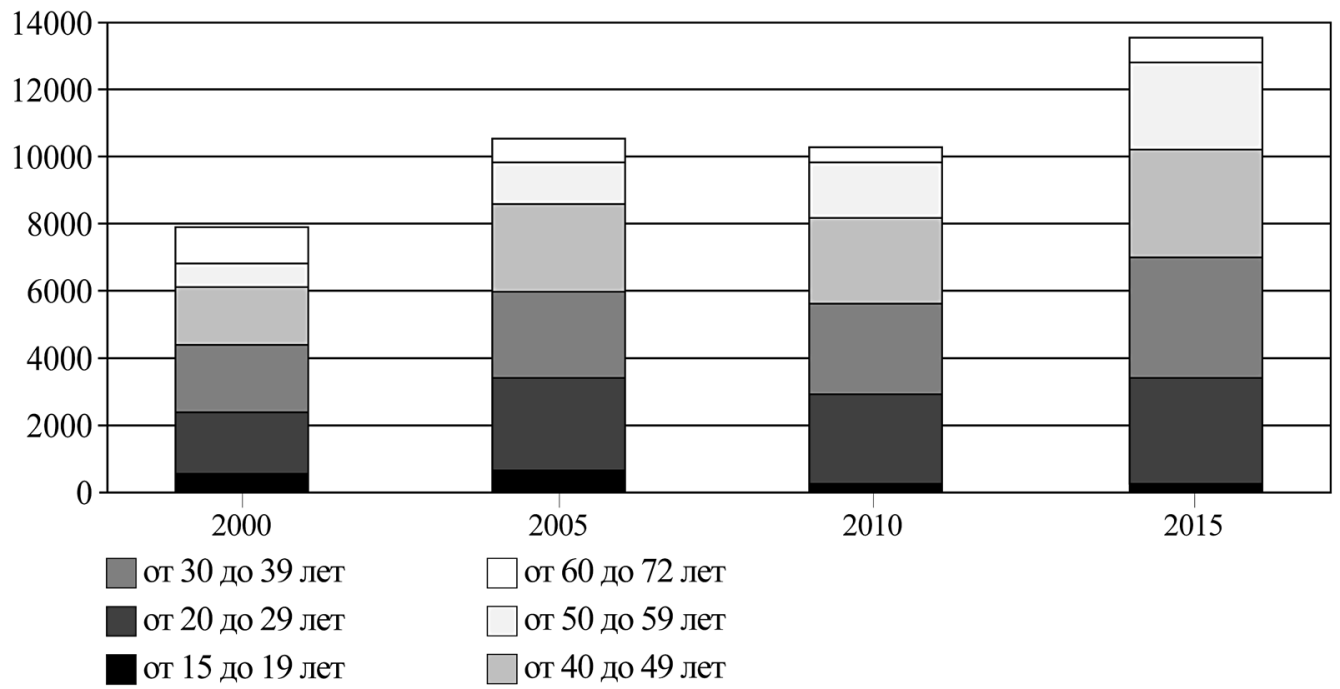

Рисунок 1. Динамика и структура численности занятости в НФС на основной работе по возрастным группам, 2000, 2005, 2010 и 2015 гг., ОРС, тыс. чел. Источник: расчеты автора.

Однако несмотря на очевидное доминирование занятости в ФС среди работников основных трудоспособных возрастов, вполне очевидна тенденция к увеличению деформализации занятости (рисунок 2). Аналогичная динамика характерна и для 50-59-летних работников: в 2000-2015 гг. уровень их занятости в НФС увеличился с 7,7 до 16\%. Среди занятых старше 60 лет, напротив, наблюдалось падение доли работающих в НФС - с 32\% в 2000 г. до 17,5\% в 2010 г. В дальнейшем произошел рост показателя, который в 2015 г. достиг 20,6\%, составив одно из максимальных значений вовлеченности в НФС среди всех возрастных категорий в этом году, и мог стать реакцией на ухудшение макроэкономической ситуации в стране [Сонина, Колосницьна 2015].

Изучение уровней занятости в НФС по дезагрегированным возрастным группам, выделенным на основе пятилетних интервалов, показывает, что российские работники в основных трудоспособных возрастах в целом стремятся оставаться занятыми в ФС. Наибольшие значения вовлеченности в неформальность характерны для самой пожилой категории работников - старше 65 лет (Приложение, таблица B). Это согласуется с данными международной статистики, которая 
фиксирует значительное присутствие неформальных работников именно в самых старших возрастах. При этом в данной категории работников произошло и наиболее активное снижение показателя вовлеченности в НФС - с 47,5\% в 2000 г. до 26-29\% в 2010-2015 гг.

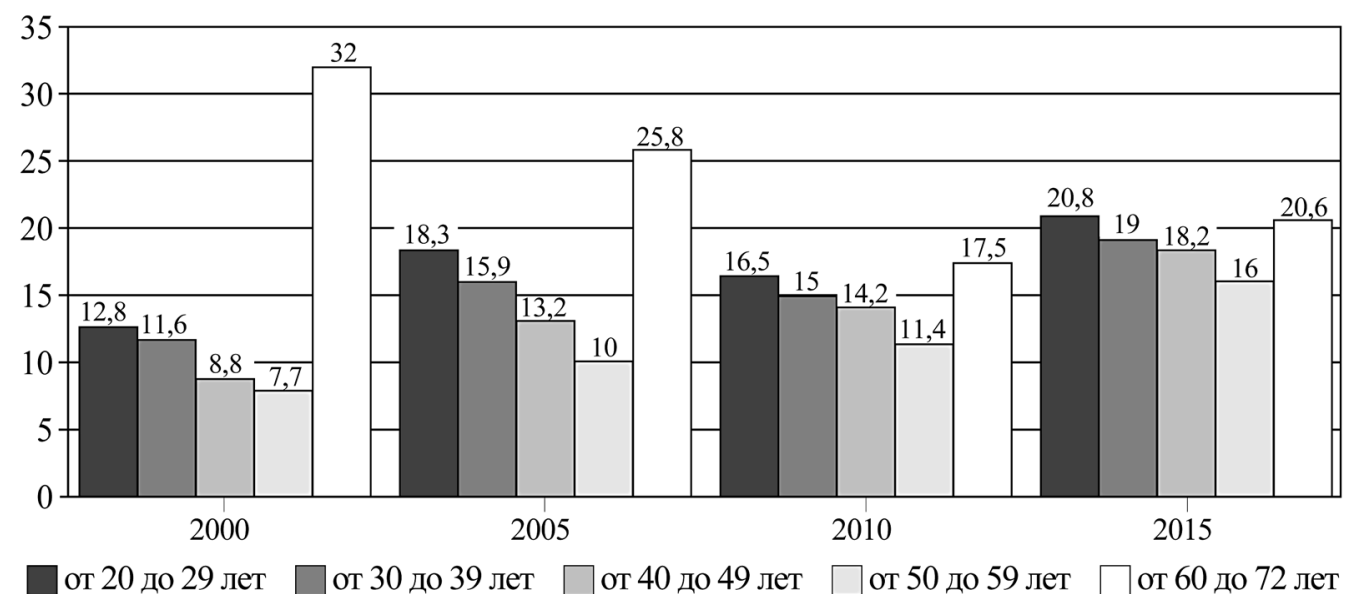

Рисунок 2. Динамика уровней занятости в НФС, ОРС, 2000-2015 гг., \% от всех занятых в данной возрастной категории

Источник: расчеты автора.

В возрастных группах 55-59 лет и 60-64 лет уровни занятости в НФС гораздо ниже, при этом чем моложе работники, тем меньше среди них соответствующая доля неформальных работников. Наблюдавшийся в 2000 и 2005 гг. разрыв между возрастными группами 50-54 лет, 55-59 лет и 60-64 лет к 2010 и 2015 гг. заметно сгладился, и уровни занятости в НФС стали примерно одинаковыми (11-13\% в 2010 г. и 15-18\% в 2015 г.). Это произошло одновременно за счет увеличения уровня занятости в НФС среди работников предпенсионных возрастов (50-54 лет) и снижения аналогичного показателя в категории занятых 60-64 лет.

Рост уровня занятости в НФС среди 50-54-летних может частично объясняться ухудшением сравнительных перспектив поиска работы и карьерного продвижения в ФС на российском рынке труда для работников ранних предпенсионных возрастов, в результате которого они перемещаются в неформальность. Однако одновременно с этим именно в группе 50-54-летних уровень занятости в ФС был близок к максимальным значениям (около $88 \%$ в 2010 г. и $83 \%$ в 2015 г.). Примечательно также то, что в группах занятых 55-59 лет и 60-64 лет в течение 2000-2010 гг. происходило снижение уровня вовлеченности в НФС, однако в межкризисный период (2010-2015 гг.), как и среди основных трудоспособных возрастов, наблюдался выраженный рост показателя, который может являться сигналом усложнения доступа в сектор формальных рабочих мест [Сонина, Колосницына 2015]. В результате описываемых процессов к концу периода различия в показателях занятости в НФС между работниками предпенсионного и пенсион- 
ного возраста практически исчезли. Исключение составила лишь самая старшая возрастная категория с ее устойчиво более высокими показателями вовлеченности в неформальность.

Таблица 1. Структура занятости в НФС на основной работе по ключевым видам занятости в возрастных группах в 2000, 2005, 2010 и 2015 гг., ОРС, \% по строке

\begin{tabular}{|c|c|c|c|}
\hline $\begin{array}{l}\text { Возрастные } \\
\text { групाшы }\end{array}$ & $\begin{array}{c}\text { В сфере } \\
\text { предпринимательской } \\
\text { деятельности без образования } \\
\text { юридического лица }\end{array}$ & $\begin{array}{c}\text { По найму } \\
\text { у физических лиц, } \\
\text { индивидуальных } \\
\text { предпринимателей }\end{array}$ & $\begin{array}{c}\text { В домашнем хозяйстве } \\
\text { по производству } \\
\text { продукции сельского } \\
\text { и лесного хозяйства }\end{array}$ \\
\hline \multicolumn{4}{|c|}{2000 г. } \\
\hline 20-29 лет & 29,9 & 48,6 & 21,6 \\
\hline 30-39 лет & 41,8 & 35,3 & 22,9 \\
\hline 40-49 лет & 39,3 & 33,8 & 26,9 \\
\hline 50-59 лет & 27,3 & 19,3 & 53,4 \\
\hline $\begin{array}{l}60 \text { лет - } \\
72 \text { года }\end{array}$ & 3,8 & 2,8 & 93,4 \\
\hline \multicolumn{4}{|c|}{2005 г. } \\
\hline 20-29 лет & 15,7 & 71,9 & 11,9 \\
\hline 30-39 лет & 28,5 & 59,0 & 11,3 \\
\hline 40-49 лет & 32,2 & 50,5 & 16,0 \\
\hline 50-59 лет & 26,0 & 45,9 & 26,9 \\
\hline $\begin{array}{l}60 \text { лет - } \\
72 \text { года }\end{array}$ & 7,8 & 13,1 & 78,9 \\
\hline \multicolumn{4}{|c|}{2010 г. } \\
\hline 20-29 лет & 40,7 & 45,0 & 14,3 \\
\hline 30-39 лет & 48,9 & 38,7 & 12,5 \\
\hline 40-49 лет & 51,4 & 32,1 & 16,5 \\
\hline 50-59 лет & 45,8 & 28,3 & 25,9 \\
\hline $\begin{array}{l}60 \text { лет - } \\
72 \text { года }\end{array}$ & 18,7 & 13,3 & 68,0 \\
\hline \multicolumn{4}{|c|}{2015 г. } \\
\hline 20-29 лет & 56,8 & 35,4 & 7,8 \\
\hline 30-39 лет & 63,3 & 30,2 & 6,5 \\
\hline 40-49 лет & 64,0 & 27,5 & 8,5 \\
\hline 50-59 лет & 59,3 & 24,3 & 16,4 \\
\hline $\begin{array}{l}60 \text { лет - } \\
72 \text { года }\end{array}$ & 34,9 & 12,4 & 52,8 \\
\hline
\end{tabular}

Источник: расчеты автора. 
В таблище 1 представлена структура занятости в НФС на основной работе по ключевым видам занятости. Следует отметить, что в основных трудоспособных возрастах среди занятых в НФС доминируют предпринимательская деятельность без образования юридического лица ${ }^{6}$ и занятость по найму у физических лиц или индивидуальных предпринимателей; при этом в 2010 и 2015 гг. на первую приходилось 50-60\% всех неформальных работников в возрасте 20-49 лет. В домашнем хозяйстве было занято в среднем не более четверти неформальных работников в каждой возрастной категории. В противоположность этому среди неформальных работников старше 60 лет во все анализируемые годы преобладали занятые в домашнем хозяйстве, что согласуется с международной статистикой, согласно которой производство в домашнем хозяйстве является одним из наиболее распространенных видов неформальной занятости в старших возрастах. Соответствующая доля в России варьировалась от 93\% в 2000 г. до 53\% в 2015 г., и отмеченное снижение в категории старше 60 лет происходило за счет увеличения доли занятых различными вариантами предпринимательской деятельности (с 4\% в 2000 г. до 35\% в 2015 г.).

Среди неформальных работников 50-59 лет структура занятости была еще более изменчивой, и к 2010-2015 гг. стала похожа на распределение видов неформальной занятости в основных трудоспособных возрастах: так, в 2000 г. в ней доминировали занятые в домашнем хозяйстве (53\%), в 2005 г. - занятые по найму (46\%), а в 2010 и 2015 гг. - занятые различными вариантами предпринимательской деятельности (46-59\%).

\section{Социально-демографическая структура занятости работников старших возрастов в российском неформальном секторе}

В структуре занятости в НФС в исследуемый период в основных трудоспособных возрастах устойчиво преобладали мужчины (52-59\%), а к 2010 г. аналогичная ситуация наблюдалась и в возрастной группе 50-59 лет (53-54\%) (таблища 2). В противоположность этому среди неформальных работников 60-72 лет доминировали женщины (54-58\%), что отражает как гендерную асимметрию российской половозрастной пирамиды, так и относительное возрастание доли женщин в сельском хозяйстве [Лукьянова, Капелюшников 2019], составляющем основу неформальной занятости в этих возрастах.

Анализ занятости в НФС по типу поселения показывает, что с возрастом доля сельских жителей среди них стабильно увеличивалась, при этом в основных трудоспособных возрастах структура занятости в НФС была смещена в сторону горожан (таблица 3). Среди неформальных работников в возрасте 50-59 лет также доминировали городские жители (58-61\%), в то время как в категории работников старше 60 лет, напротив, продолжительное время преобладали жители сел. Однако к 2015 г. структура занятости в НФС в данной возрастной категории также сместилась в сторону проживающих в городах, а доля жителей сел последовательно сократилась с 81 до $44 \%$.

6 Сюда в соответствии с методологией Росстата также были отнесены фермеры и занятые на индивидуальной основе. 
Таблица 2. Структура занятости в НФС на основной работе по полу в возрастных группах в 2000, 2005, 2010 и 2015 гг., ОРС, \% по возрастной группе в конкретном году

\begin{tabular}{|l|c|c|c|c|c|c|c|c|}
\hline \multirow{2}{*}{$\begin{array}{l}\text { Возрастные } \\
\text { групшы }\end{array}$} & \multicolumn{2}{|c|}{2000 г. } & \multicolumn{2}{c|}{2005 г. } & \multicolumn{2}{c|}{2010 г. } & \multicolumn{2}{c|}{2015 г. } \\
\cline { 2 - 10 } & $\begin{array}{c}\text { Муж- } \\
\text { чины }\end{array}$ & $\begin{array}{c}\text { Жен- } \\
\text { щины }\end{array}$ & $\begin{array}{c}\text { Муж- } \\
\text { чины }\end{array}$ & $\begin{array}{c}\text { Жен- } \\
\text { щины }\end{array}$ & $\begin{array}{c}\text { Муж- } \\
\text { чины }\end{array}$ & $\begin{array}{c}\text { Жен- } \\
\text { щины }\end{array}$ & $\begin{array}{c}\text { Муж- } \\
\text { чины }\end{array}$ & $\begin{array}{c}\text { Жен- } \\
\text { щины }\end{array}$ \\
\hline $20-29$ лет & 52,7 & 47,3 & 52,9 & 47,1 & 57,8 & 42,2 & 58,6 & 41,4 \\
\hline $30-39$ лет & 55,3 & 44,7 & 53,3 & 46,7 & 56,8 & 43,2 & 57,8 & 42,2 \\
\hline $40-49$ лет & 52,8 & 47,2 & 51,5 & 48,5 & 55,2 & 44,8 & 55,0 & 45,0 \\
\hline $50-59$ лет & 44,4 & 55,6 & 49,0 & 51,0 & 54,0 & 46,0 & 53,3 & 46,7 \\
\hline 60 лет-72 года & 43,7 & 56,3 & 41,6 & 58,4 & 46,1 & 53,9 & 46,4 & 53,6 \\
\hline
\end{tabular}

Источник: расчеты автора.

Таблица 3. Структура занятости в НФС на основной работе по типу поселения в возрастных группах в 2000, 2005, 2010 и 2015 гг., ОРС, \% по возрастной группе в конкретном году

\begin{tabular}{|l|c|c|c|c|c|c|c|c|}
\hline \multirow{2}{*}{$\begin{array}{l}\text { Воз- } \\
\text { растные } \\
\text { групшы }\end{array}$} & \multicolumn{2}{|c|}{$\mathbf{2 0 0 0}$ г. } & \multicolumn{2}{c|}{$\mathbf{2 0 0 5}$ г. } & \multicolumn{2}{c|}{$\mathbf{2 0 1 0}$ г. } & \multicolumn{2}{c|}{$\mathbf{2 0 1 5}$ г. } \\
\cline { 2 - 10 } & Город & Село & Город & Село & Город & Село & Город & Село \\
\hline $20-29$ лет & 66,9 & 33,1 & 68,1 & 31,9 & 64,1 & 35,9 & 66,7 & 33,3 \\
\hline $30-39$ лет & 64,6 & 35,4 & 69,5 & 30,5 & 66,9 & 33,1 & 68,1 & 31,9 \\
\hline $40-49$ лет & 61,2 & 38,8 & 62,8 & 37,2 & 61,6 & 38,4 & 65,4 & 34,6 \\
\hline $50-59$ лет & 43,1 & 56,9 & 59,5 & 40,5 & 57,5 & 42,5 & 60,8 & 39,2 \\
\hline 60 лет - 72 года & 18,8 & 81,2 & 33,7 & 66,3 & 47,2 & 52,8 & 55,9 & 44,1 \\
\hline
\end{tabular}

Источник: расчеты автора.

В таблице 4 представлено распределение работников НФС в зависимости от возраста и уровня образования. Известно, что неформальная занятость, как правило, сопряжена с невысоким образованием, и потому вполне ожидаемо, что среди основных трудоспособных возрастов преимущественные риски неформальной занятости сосредоточены среди тех, кто имеет среднее профессиональное, начальное профессиональное или среднее (полное) общее образование. Работники 50-59 лет также не являются исключением. На каждую категорию с соответствующим уровнем образования приходилось около 20-30\% всех занятых в НФС в этом возрасте. Работники старших возрастов с низкими уровнями образования, как правило, не могут конкурировать за рабочие места с более молодыми, которые в среднем являются более образованными [Лукьянова, Капелюшников 2019] (что отражает общие изменения образовательной структуры рынка труда) и имеют больше шансов получить работу в формальном секторе. 
Таблица 4. Структура занятости в неформальном секторе на основной работе по уровню образования в возрастных группах в 2000, 2005, 2010 и 2015 гг., ОРС, \% по строке

\begin{tabular}{|c|c|c|c|c|c|c|c|}
\hline $\begin{array}{l}\text { Воз- } \\
\text { растные } \\
\text { групाыы }\end{array}$ & $\begin{array}{c}\text { Высшее } \\
\text { профес- } \\
\text { сиональ- } \\
\text { ное }\end{array}$ & $\begin{array}{c}\text { Неполное } \\
\text { высшее } \\
\text { профес- } \\
\text { сиональное }\end{array}$ & $\begin{array}{c}\text { Среднее } \\
\text { профес- } \\
\text { сиональ- } \\
\text { ное }\end{array}$ & $\begin{array}{c}\text { Начальное } \\
\text { профес- } \\
\text { сиональ- } \\
\text { ное }\end{array}$ & $\begin{array}{c}\text { Среднее } \\
\text { (полное) } \\
\text { общее }\end{array}$ & $\begin{array}{c}\text { Основное } \\
\text { общее }\end{array}$ & $\begin{array}{c}\text { Начальное } \\
\text { общее } \\
\text { или не имеют } \\
\text { начального } \\
\text { общего }\end{array}$ \\
\hline \multicolumn{8}{|c|}{2000 г. } \\
\hline 20-29 лет & 7,7 & 4,7 & 26,4 & 14,0 & 33,0 & 12,8 & 1,4 \\
\hline 30-39 лет & 12,8 & 3,2 & 32,2 & 11,8 & 30,7 & 8,2 & 1,1 \\
\hline $40-49$ лет & 12,5 & 2,6 & 30,0 & 9,3 & 31,4 & 11,8 & 2,2 \\
\hline 50-59 лет & 12,6 & 2,4 & 20,7 & 6,3 & 22,8 & 21,6 & 13,5 \\
\hline $\begin{array}{l}60 \text { лет - } \\
72 \text { года }\end{array}$ & 4,5 & 0,9 & 9,6 & 4,6 & 12,3 & 23,8 & 44,3 \\
\hline \multicolumn{8}{|c|}{2005 г. } \\
\hline 20-29 лет & 9,1 & 4,4 & 18,8 & 23,4 & 32,3 & 11,0 & 1,1 \\
\hline 30-39 лет & 12,9 & 2,0 & 21,9 & 23,3 & 31,3 & 8,1 & 0,5 \\
\hline 40-49 лет & 12,6 & 0,9 & 23,8 & 21,3 & 32,6 & 8,2 & 0,6 \\
\hline 50-59 лет & 11,3 & 0,8 & 23,2 & 17,8 & 31,2 & 14,2 & 1,6 \\
\hline $\begin{array}{l}60 \text { лет - } \\
72 \text { года }\end{array}$ & 7,8 & 0,5 & 11,4 & 9,5 & 18,0 & 33,2 & 19,5 \\
\hline \multicolumn{8}{|c|}{2010 г. } \\
\hline 20-29 лет & 14,6 & - & 19,5 & 22,1 & 34,2 & 8,3 & 1,0 \\
\hline 30-39 лет & 15,0 & - & 21,2 & 23,3 & 32,0 & 7,8 & 0,7 \\
\hline 40-49 лет & 14,2 & - & 24,3 & 24,1 & 31,4 & 5,4 & 0,5 \\
\hline 50-59 лет & 12,7 & - & 25,8 & 20,5 & 31,5 & 8,5 & 1,0 \\
\hline $\begin{array}{l}60 \text { лет - } \\
72 \text { года } \\
\end{array}$ & 13,2 & - & 18,8 & 14,4 & 24,8 & 21,7 & 7,1 \\
\hline \multicolumn{8}{|c|}{2015 г. } \\
\hline 20-29 лет & 15,3 & - & 19,5 & 21,7 & 33,5 & 7,1 & 0,6 \\
\hline 30-39 лет & 17,4 & - & 19,3 & 23,7 & 30,6 & 6,9 & 0,7 \\
\hline 40-49 лет & 15,3 & - & 23,5 & 25,3 & 29,5 & 5,6 & 0,3 \\
\hline 50-59 лет & 14,1 & - & 25,5 & 24,2 & 30,1 & 5,6 & 0,3 \\
\hline $\begin{array}{l}60 \text { лет - } \\
72 \text { года }\end{array}$ & 16,5 & - & 26,1 & 19,8 & 25,0 & 11,3 & 1,2 \\
\hline
\end{tabular}

Источник: расчеты автора. 
Более половины неформальных работников старше 60 лет на протяжении 2000-2005 гг. имели самые низкие уровни образования (основное общее, начальное общее или без образования). Позднее преобладающими категориями стали занятые со средним профессиональным и средним (полным) общим образованием. Доля тех, кто имеет основное общее образование или ниже, в 2015 г. значительно сократилась и составила чуть более $12 \%$. Это свидетельствует как о естественном уходе с рынка труда наименее образованных пожилых работников, так и об относительном повышении уровня образования среди работников НФС в старших возрастах. В пользу этого говорит и увеличение доли занятых, имеющих высшее профессиональное образование: так, если в 2000 г. она составляла всего 4,5\% от всех неформальных работников старше 60 лет, то к 2015 г. ее значение превысило 16\%, тем самым демонстрируя тенденцию к ограничению спроса на труд работников преклонного возраста с высшим образованием в ФС. Совокупность отмеченных процессов привела к увеличению сходства в образовательной структуре неформальных работников основных трудоспособных и пожилых возрастов.

\section{Профессиональные и отраслевые характеристики занятости работников старших возрастов в российском неформальном секторе}

В таблице 5 представлено распределение неформальных работников различных возрастов в зависимости от профессии. В исследуемый период в основных трудоспособных возрастах наибольшие риски занятости в НФС устойчиво концентрировались среди работников сферы обслуживания и ЖКХ (от 20 до 30\%). Среди работников старших возрастов структура неформальной занятости по профессиям была гораздо менее стабильной. В 2000 г. квалифицированные работники сельского и лесного хозяйства составляли более $90 \%$ неформальных работников старше 60 лет и почти половину неформально занятых в возрасте 50-59 лет, однако к 2005 г. присутствие данной профессиональной группы среди неформальных работников старших возрастов значительно сократилось. В первую очередь это затронуло категорию работников 50-59 лет. Уже к 2005 г. доля квалифицированных работников сельского и лесного хозяйства упала до трети, а к 2015 г. она составляла немногим менее одной пятой всех неформальных работников данных возрастов. Основной причиной этого падения является не только увеличение доли работников сферы обслуживания и ЖКХ (с 17 до 23\%), но и возрастание присутствия в структуре неформальных работников 50-59 лет руководителей (с 2 до 14\%), а также операторов, аппаратчиков и машинистов (с 5,6 до 13,6\%). При этом доля специалистов высшей и средней квалификации в структуре занятости в НФС среди 50-59-летних оставалась неизменной и составляла 3-5\%.

Среди неформальных работников старше 60 лет также произошло значительное падение доли квалифицированных работников сельского хозяйства, однако данная профессиональная группа не утратила свою доминирующую позицию в структуре занятости: в 2015 г. к ней относились чуть менее $55 \%$ всех 


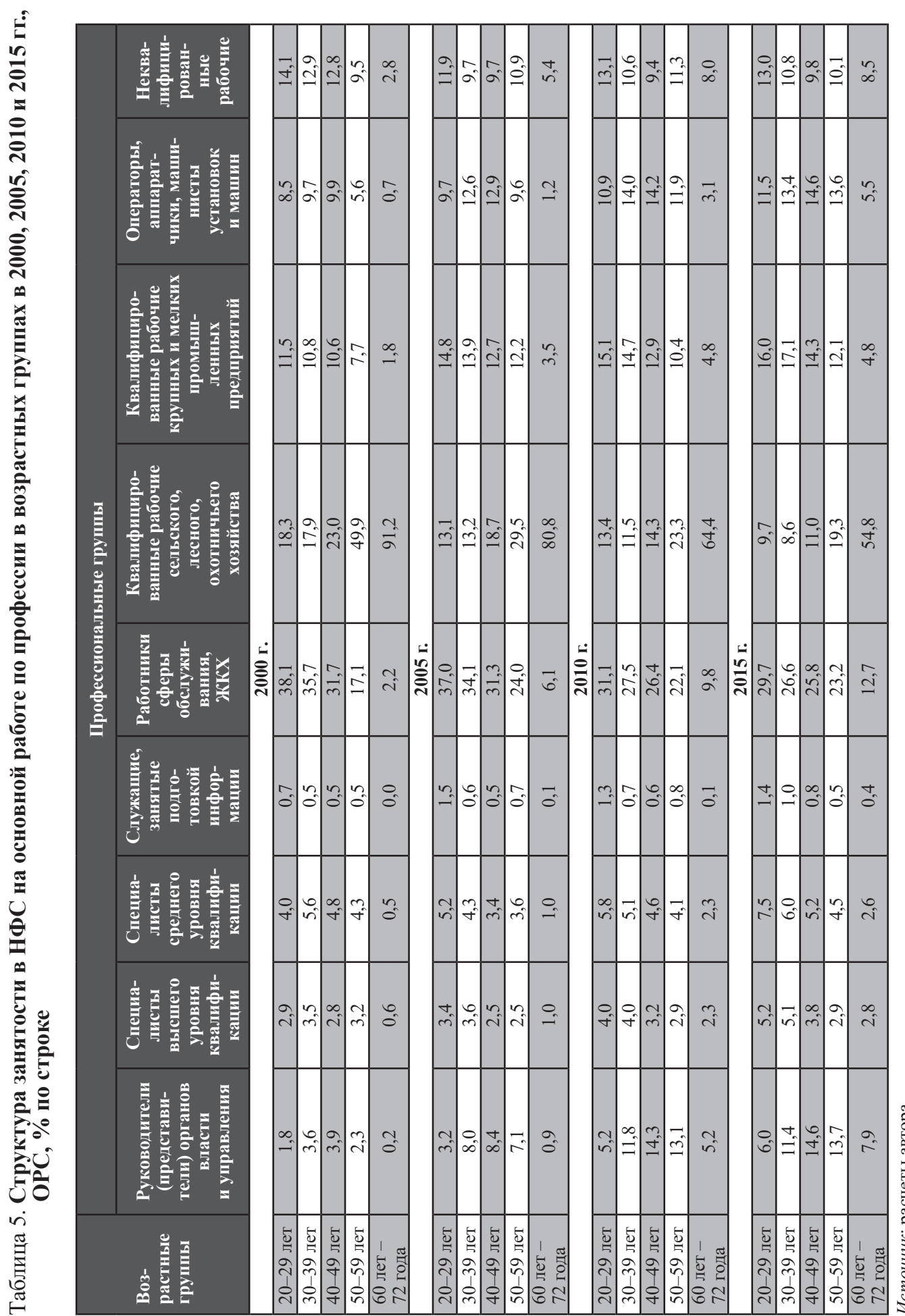


занятых в НФС старше 60 лет. Сокращение ее присутствия в структуре неформальной занятости работников преклонного возраста произошло на фоне увеличения доли руководителей (с 0,2 до 8\%), работников сферы обслуживания и ЖКХ (с 2 до 13\%), операторов, аппаратчиков и машинистов (с 0,7 до 5,5\%) и неквалифицированных рабочих (с 3 до 8,5\%). Следовательно, можно отметить нарастание профессиональной поляризации ${ }^{7}$ занятости работников НФС в старших возрастах, которое происходит на фоне роста их вовлеченности в предпринимательскую деятельность различного типа, описанную выше. По-видимому, на одном конце этой поляризованной неформальности находились индивидуальное предпринимательство и занятость в фермерских хозяйствах, а на втором - низкоквалифицированная самозанятость, связанная с ручным трудом и рабочими профессиями.

Динамика профессиональной принадлежности работников тесно связана с изменением структуры их занятости по отраслям (таблица б). Среди неформальных работников в основных трудоспособных возрастах во все годы наблюдения преобладали занятые в оптовой и розничной торговле, доля которых составляла около $35-40 \%$. Следующей по размеру являлась категория занятых в сельском хозяйстве: в 2000-2010 гг. к ней относилось около 20-30\% работников НФС в возрасте 20-49 лет; к 2015 г. присутствие работников данной отрасли в общей структуре неформальной занятости значительно сократилось, и соответствующие доли не превышали $16 \%$. В структуре неформальной занятости 50-59-летних прослеживались сходные тенденции: абсолютное доминирование занятых в сельском хозяйстве в 2000 г., которые составляли около 58\% всех неформальных работников в возрасте 50-59 лет, сменилось преобладанием работников торговли, чья доля увеличилась с 24 до 34\%; к 2015 г. сельское хозяйство переместилось на второе место в отраслевой структуре неформальной занятости 50-59-летних, теперь в нем был занят лишь каждый четвертый.

Заметна также тенденция к росту двух других традиционных отраслей НФС строительства и транспорта: если в 2000 г. среди 50-59-летних неформальных работников в строительстве было занято около $4 \%$, а на транспорте - чуть более $2 \%$, то к 2015 г. показатель увеличился до 9,7 и 9,5\% соответственно. В структуре неформальных работников старше 60 лет также произошло значительное сокращение доли занятых в сельском хозяйстве, однако к 2015 г. данная отрасль не утратила своего господствующего положения: если в 2000 г. в сельском хозяйстве было занято более $90 \%$ всех неформальных работников преклонного возраста, то в 2015 г. показатель составлял более 57\%. Сокращение присутствия сельского хозяйства в отраслевой структуре занятости работников 60-72 лет сопровождалось активным увеличением доли занятых в торговле (с 3 до 19\%), а также приростом доли работников строительства и транспорта (с 0,2 и 0,5\% в 2000 г. до 3,8 и 4,6\% в 2015 г. соответственно).

\footnotetext{
7 Профессиональная поляризация является универсальной характеристикой занятости работников старших возрастов в России, см. [Лукьянова, Капелюшников 2019].
} 
Таблица 6. Структура занятости в НФС на основной работе по отраслям в возрастных группах в 2000, 2005, 2010 и 2015 гг., ОРС, \% по столбцу

\begin{tabular}{|c|c|c|c|c|c|}
\hline \multirow{2}{*}{ Отрасли занятости } & \multicolumn{5}{|c|}{ Возрастные групшы } \\
\hline & 20-29 лет & 30-39 лет & 40-49 лет & 50-59 лет & 60 лет -72 года \\
\hline \multicolumn{6}{|c|}{2000 г. } \\
\hline Сельское хозяйство & 25,4 & 26,0 & 32,2 & 57,6 & 92,6 \\
\hline Рыболовство & 0,1 & 0,2 & 0,1 & 0,0 & 0,0 \\
\hline Добыча полезных ископаемых & 0,1 & 0,1 & 0,1 & 0,0 & 0,1 \\
\hline Обрабатывающие производства & 6,4 & 5,6 & 5,2 & 3,5 & 1,7 \\
\hline Электроэнергия, газ, вода & 0,0 & 0,0 & 0,1 & 0,1 & 0,0 \\
\hline Строительство & 4,2 & 3,6 & 4,3 & 4,3 & 0,2 \\
\hline Торговля, ремонт автотранспорта & 47,5 & 46,6 & 42,6 & 23,6 & 2,8 \\
\hline Гостиницы и рестораны & 1,6 & 1,3 & 1,3 & 0,4 & 0,0 \\
\hline Транспорт и связь & 3,7 & 5,1 & 4,7 & 2,4 & 0,5 \\
\hline Финансовая деятельность & 0,1 & 0,1 & 0,0 & 0,1 & 0,1 \\
\hline Недвижимость, деловые услуги & 1,8 & 2,0 & 1,7 & 1,2 & 0,2 \\
\hline Государственное управление & 0,3 & 0,2 & 0,1 & 0,3 & 0,0 \\
\hline Образование & 0,3 & 0,3 & 0,2 & 0,2 & 0,1 \\
\hline Здравоохранение & 0,3 & 0,7 & 0,2 & 0,5 & 0,1 \\
\hline $\begin{array}{l}\text { Предоставление коммунальных, } \\
\text { социальных и персональных услуг }\end{array}$ & 8,0 & 7,9 & 6,8 & 5,3 & 1,4 \\
\hline Ведение частных домашних хозяйств & 0,2 & 0,4 & 0,2 & 0,4 & 0,1 \\
\hline \multicolumn{6}{|c|}{2005 г. } \\
\hline Сельское хозяйство & 15,4 & 15,9 & 22,2 & 33,3 & 80,2 \\
\hline Рыболовство & 0,3 & 0,4 & 0,3 & 0,5 & 0,6 \\
\hline Добыча полезных ископаемых & 0,1 & 0,1 & 0,2 & 0,1 & 0,0 \\
\hline Обрабатывающие производства & 9,5 & 9,0 & 8,9 & 9,3 & 4,4 \\
\hline Электроэнергия, газ, вода & 0,1 & 0,1 & 0,2 & 0,3 & 0,1 \\
\hline Строительство & 10,6 & 9,9 & 9,0 & 8,1 & 0,9 \\
\hline Торговля, ремонт автотранспорта & 46,0 & 46,6 & 43,1 & 34,4 & 8,2 \\
\hline Гостиницы и рестораны & 3,2 & 2,6 & 1,8 & 2,1 & 0,8 \\
\hline Транспорт и связь & 7,0 & 8,1 & 8,7 & 5,7 & 1,5 \\
\hline Финансовая деятельность & 0,1 & 0,0 & 0,2 & 0,2 & 0,1 \\
\hline Недвижимость, деловые услуги & 3,1 & 2,7 & 1,8 & 1,8 & 0,7 \\
\hline Государственное управление & 0,0 & 0,0 & 0,0 & 0,1 & 0,0 \\
\hline Образование & 0,5 & 0,3 & 0,3 & 0,6 & 0,8 \\
\hline Здравоохранение & 0,4 & 0,6 & 0,6 & 0,8 & 0,3 \\
\hline
\end{tabular}


Работники стариих возрастов в российском неформальном секторе:

маситаб, динамика и структура занятости, стр. 72-97

\begin{tabular}{|c|c|c|c|c|c|}
\hline $\begin{array}{l}\text { Предоставление коммунальных, } \\
\text { социальных и персональных услуг }\end{array}$ & 3,7 & 3,5 & 2,4 & 2,1 & 1,2 \\
\hline Ведение частных домашних хозяйств & 0,1 & 0,2 & 0,3 & 0,6 & 0,3 \\
\hline \multicolumn{6}{|c|}{2010 г. } \\
\hline Сельское хозяйство & 18,1 & 17,4 & 21,6 & 31,2 & 65,1 \\
\hline Рыболовство & 0,2 & 0,2 & 0,2 & 0,2 & 0,2 \\
\hline Добыча полезных ископаемых & 0,1 & 0,1 & 0,1 & 0,1 & 0,0 \\
\hline Обрабатывающие производства & 8,8 & 9,1 & 8,8 & 8,4 & 7,1 \\
\hline Электроэнергия, газ, вода & 0,2 & 0,2 & 0,2 & 0,3 & 0,1 \\
\hline Строительство & 12,9 & 12,5 & 10,4 & 8,3 & 2,5 \\
\hline Торговля, ремонт автотранспорта & 39,1 & 38,7 & 38,2 & 33,3 & 15,0 \\
\hline Гостиницы и рестораны & 2,9 & 1,9 & 1,9 & 1,9 & 0,8 \\
\hline Транспорт и связь & 7,7 & 10,1 & 9,9 & 8,2 & 2,8 \\
\hline Финансовая деятельность & 0,3 & 0,3 & 0,2 & 0,2 & 0,1 \\
\hline Недвижимость, деловые услуги & 3,8 & 3,5 & 3,0 & 2,7 & 2,6 \\
\hline Государственное управление & 0,0 & 0,0 & 0,0 & 0,0 & 0,0 \\
\hline Образование & 0,5 & 0,4 & 0,5 & 0,5 & 0,6 \\
\hline Здравоохранение & 0,6 & 0,9 & 0,9 & 1,1 & 0,9 \\
\hline $\begin{array}{l}\text { Предоставление коммунальных, } \\
\text { социальных и персональных услуг }\end{array}$ & 4,8 & 4,5 & 3,8 & 3,2 & 1,8 \\
\hline Ведение частных домашних хозяйств & 0,1 & 0,2 & 0,3 & 0,3 & 0,2 \\
\hline \multicolumn{6}{|c|}{2015 г. } \\
\hline Сельское хозяйство & 13,0 & 12,6 & 15,9 & 25,4 & 57,1 \\
\hline Рыболовство & 0,3 & 0,3 & 0,3 & 0,3 & 0,5 \\
\hline Добыча полезных ископаемых & 0,1 & 0,2 & 0,2 & 0,1 & 0,1 \\
\hline Обрабатывающие производства & 9,1 & 10,6 & 9,7 & 9,0 & 5,1 \\
\hline Электроэнергия, газ, вода & 0,2 & 0,3 & 0,2 & 0,3 & 0,1 \\
\hline Строительство & 14,0 & 15,0 & 11,6 & 9,7 & 3,8 \\
\hline Торговля, ремонт автотранспорта & 35,9 & 35,5 & 36,1 & 33,5 & 18,7 \\
\hline Гостиницы и рестораны & 4,8 & 3,2 & 3,0 & 2,8 & 1,7 \\
\hline Транспорт и связь & 9,1 & 10,1 & 11,4 & 9,5 & 4,6 \\
\hline Финансовая деятельность & 0,4 & 0,2 & 0,3 & 0,1 & 0,1 \\
\hline Недвижимость, деловые услуги & 4,9 & 4,4 & 4,2 & 3,6 & 3,3 \\
\hline Государственное управление & - & - & - & - & - \\
\hline Образование & 0,6 & 0,5 & 0,6 & 0,6 & 1,0 \\
\hline Здравоохранение & 0,8 & 0,8 & 1,1 & 1,0 & 0,9 \\
\hline $\begin{array}{l}\text { Предоставление коммунальных, } \\
\text { социальных и персональных услуг }\end{array}$ & 6,6 & 6,1 & 5,2 & 3,8 & 2,9 \\
\hline Ведение частных домашних хозяйств & 0,1 & 0,1 & 0,2 & 0,3 & 0,2 \\
\hline
\end{tabular}

Источник: расчеты автора. 


\section{Заключение}

Неформальная занятость представляет собой один из важнейших вызовов для современной пенсионной системы и системы социальной защиты [Синявская 2017], а неформальная занятость пожилых является еще и сигналом неблагополучия текущего и предшествующего положения на рынке труда, которое вынуждает обратиться за дополнительными источниками дохода в НФС. Для России изучение особенностей неформальной занятости в старших возрастах имеет особую актуальность. Одной из причин этого является продолжительная традиция занятости в НФС среди российского населения, начало которой было положено еще в период перехода к рыночной экономике. Другая заключается в старении населения, в результате которого возрастающая нагрузка по отчислениям в социальные фонды будет ложиться на занятых в молодых и средних возрастных когортах, работающих в ФС. Целью настоящей работы был анализ долгосрочных тенденций занятости российских работников старших возрастов в неформальном секторе, которые ранее не являлись предметом отдельного изучения.

Проведенное исследование показало, что к 2015 г. на российском рынке труда в НФС были заняты более 3 млн чел. старше 50 лет. Неформальность получила наибольшее распространение среди работников преклонного возраста (старше 65 лет), в то время как формальная занятость доминировала среди работников основных трудоспособных возрастов, что согласуется со статистикой рынка труда в зарубежных странах [ILO 2018]. Одновременно с этим наблюдалась тенденция к возрастающей деформализации занятости работников 50-54 лет, которая частично может объясняться ухудшением перспектив поиска работы и карьерного продвижения для занятых в ранних предпенсионных возрастах на российском рынке труда. Среди занятых старше 60 лет, напротив, произошло падение доли работающих в НФС. Эти два процесса привели к тому, что в настоящий момент разрыв в уровнях неформальной занятости между работниками предпенсионного и пенсионного возраста в значительной степени сгладился.

Вполне ожидаемо, что в структуре занятости в НФС представлены преимущественно работники с невысокими уровнями образования, которые не могут претендовать на рабочие места в ФС. В анализируемый период среди работников старше 60 лет основные риски неформальной занятости переместились от наиболее низких уровней образования (основное общее, начальное или без образования) к среднему профессиональному и среднему (полному) общему образованию, обладатели которых доминировали в структуре неформальной занятости как в основных трудоспособных возрастах, так и среди 50-59-летних неформальных работников. Это свидетельствует о сближении образовательной структуры занятости неформальных работников разных возрастов, а также косвенно может говорить о том, что неформальные работники основных трудоспособных возрастов с течением времени продолжают оставаться занятыми в НФС.

Основные изменения в структуре неформальной занятости работников старших возрастов связаны с увеличением вовлеченности в различные варианты предпринимательской деятельности без образования юридического лица. Это произошло за счет значительного сокращения занятости в домашнем хозяйстве, которая является традиционным типом неформальной трудовой деятельности пожилых работников во многих странах, включая Россию. Описываемая динамика развива- 
лась на фоне масштабного сокращения доли сельских жителей в структуре неформальной занятости пожилых, а также падения доли занятых в сельском хозяйстве. На смену этой традиционной сфере неформальной занятости работников старших возрастов пришли такие отрасли, как торговля, транспорт и строительство. Именно в этих отраслях неформальная занятость оказывается сосредоточена и в основных трудоспособных возрастах, тем самым различия в структуре неформальной занятости работников разного возраста сглаживаются и по этому параметру. Другая важная тенденция связана с возрастанием профессиональной поляризации занятости работников неформального сектора в старших возрастах, т. е. с увеличением доли наиболее квалифицированных (руководители) и наименее квалифицированных (рабочие профессии) специальностей. При этом указанная динамика в несколько большей степени затрагивала неформальных работников в возрасте 50-59 лет, чем работников старше 60 лет, что может объясняться ограничением возможностей выполнения работы, требующей больших физических нагрузок. Увеличение доли рабочих профессий в структуре неформальной занятости работников старших возрастов, сочетающееся с общим повышением их формального образовательного уровня, может объясняться нехваткой навыков и компетенций, которая не позволяет конкурировать за рабочие места в ФС.

Подводя итоги, следует указать на возрастающее сближение образовательной и профессионально-отраслевой структуры неформальной занятости работников разных возрастов на российском рынке труда. В настоящий момент работники старших возрастов трудятся в тех же отраслях и профессиях НФС, что и более молодые его представители. Неформальный сектор предъявляет универсальный спрос на труд, и на генерируемых в нем рабочих местах трудоустраиваются как молодые, так и пожилые работники. Подобная конвергенция структур занятости в НФС, сочетающаяся с будущим вступлением в старший возраст более многочисленных когорт и возрастающей деформализацией занятости 50-59-летних, предполагает дальнейшую экспансию НФС и сокращение общего объема страховых пенсионных поступлений [Синявская 2017]. В такой ситуации необходимые меры политики должны включать комплексное развитие программ повышения квалификации и переобучения для лиц старших возрастов, создания гибких рабочих мест и облегчения легализации самозанятости.

\section{Литература}

Вишневская Н.Т. (2017) Работники старших возрастов на рынке труда в странах ОЭСР // Экономический журнал ВШЭ. Т. 21. № 4. С. 680-701.

Лукьянова А.Л. (2012) Пенсионное страхование, неформальная занятость и самозанятость. Серия WP3 «Проблемы рынка труда». WP3/2012/02. М.: ВШЭ.

Лукьянова А.Л., Капелюшников Р.И. (2019) Работники предпенсионного и пенсионного возраста на российском рынке труда: тенденции в реаллокации занятости // Вопросы экономики. № 11. С. 5-34.

Методологическое руководство для пользователей базы микроданных обследований населения по проблемам занятости (2002). М.: Росстат.

Понятия и определения (2015) // Обследование населения по проблемам занятости. M.: Росстат. C. 9-12 // https://www.gks.ru/bgd/regl/b15_30/IssWWW.exe/Stg/d04/01-5.doc

Синявская О.В. (2017) Российская пенсионная система в контексте демографических вызовов и ограничений // Экономический журнал ВШЭ. Т. 21. № 4. С. 562-591. 
Синявская О.В., Бирюкова С.С. (2018) Возможные меры снижения неформальной занятости и скрытой оплаты труда // Журнал Новой экономической ассоциации. № 1. С. 193-202.

Сонина Ю.В., Колосницына М.Г. (2015) Пенсионеры на российском рынке труда: тенденции экономической активности людей пенсионного возраста // Демографическое обозрение. Т. 2. № 2. С. 37-53.

Alvarez C.V., Potes M. del P.E., Merchán M.E.P. (2016) Quality of Life and Informal Labor among Elderly Persons in an Intermediate Colombian City, 2012-2013 // Revista Brasileira de Geriatria e Gerontologia, vol. 19, no 3, pp. 415-427.

Farber H.S. (2004) Job Loss in the United States, 1981-2001// Research in Labor Economics, vol. 23, pp. 69-117.

Gatti R., Angel-Urdinola D.F, Silva J., Bodor A. (2014) Striving for Better Jobs: The Challenge of Informality in the Middle East and North Africa // The World Bank. Directions in Development. No. 90271, Washington, DC.

Heywood J.S., Siebert W.S. (2009) Understanding the Labour Market for Older Workers: A Survey // IZA Discussion Paper Series. No. 4033.

ILO (2014). Informality and the Quality of Employment in G20 Countries. Report Prepared for the G20 Labour and Employment Ministerial Meeting Melbourne, Australia, 10-11 September 2014.

ILO (2018). Women and Men in the Informal Economy: A Statistical Picture (Third Edition). International Labour Office, Geneva: ILO.

Jütting J., Parlevliet J., Xenogiani T. (2008) Informal Employment Re-Loaded // OECD Developement Centre Working Paper. No. 266, Paris: OECD.

Kelly P. (2005) Integration and Participation of Older Persons in Development // UN Department of Economic and Social Affairs, UN Secretariat.

Lahey J.N. (2010) International Comparison of Age Discrimination Laws // Research on Aging, vol. 32, no 6, pp. 679-697.

Maloney W.F. (1999) Does Informality Imply Segmentation in Urban Labor Markets? Evidence from Sectoral Transitions in Mexico // The World Bank Economic Review. No. 13, pp. 275-302.

McCaig B., Pavcnik N. (2015) Informal Employment in a Growing and Globalizing Low-income Country // American Economic Review: Papers and Proceedings, vol. 105, no 5, pp. 545-550.

Mikkonen-Jeanneret E., Rayapova R., Yefimov N. (2011) Off the Grid: Exploring the Expanding Informal Economy and Threats to Old-age Social Protection in Kyrgyzstan and Tajikistan. Report by HelpAge International, Eastern Europe and Central Asia.

Murrugarra E. (2011) Employability and Productivity among Older Workers: A Policy Framework and Evidence from Latin America // Well-being and Social Policy, vol. 7, no 2, pp. 53-99.

OECD (2008). Declaring Work or Staying Underground: Informal Employment in Seven OECD Countries. Chapter 2 in OECD Employment Outlook, OECD, Paris, pp. 79-137.

Oude Mulders J., Wadensjö E. (2015) Domain: Labour Market // Understanding Employment Participation of Older Workers: Creating a Knowledge Base for Future Labour Market Challenges (eds. Hasselhorn H.M., Apt W.). Research Report. Federal Ministry of Labour and Social Affairs (BMAS) and Federal Institute for Occupational Safety and Health (BAuA). BMAS/ BAuA, Berlin, pp. 31-40.

Perron R. (2018) The Value of Experience: Age Discrimination against Older Workers Persists, Washington, DC: AARP.

Perry G.E., Maloney W.F., Arias O.S., Fajnzylber P., Mason A.D., Saavedra-Chanduvi J. (2007) Informality: Exit and Exclusion. Latin America and the Caribbean Studies Report, Washington, DC: The World Bank.

Sahoo B., Neog B.G. (2015) Heterogeneity and Participation in Informal Employment among Non-cultivator Workers in India // MPRA Paper. No. 68136, University Library of Munich.

Stuart E., Samman E., Hunt A. (2018) Informal Is the New Normal. Improving the Lives of Workers at Risk of Being Left Behind // Overseas Development Institute Working Paper Series. Working Paper. No. 530.

The World Bank (2009). Federative Republic of Brazil: Social Insurance and Labor Supply: Assessing Incentives and Redistribution. Human Development Sector Management Unit, Latin America and the Caribbean Region, The World Bank, Washington, DC.

Tondini A., Ardington C., Woolard I. (2017) Public Pensions and Elderly Informal Employment: Evidence from a Change in Retirement Age in South Africa // SALDRU. Working Paper. No. 206. 


\section{Приложение}

Таблица А. Структура занятости в НФС на основной работе по возрастным группам и ее динамика в 2000, 2005, 2010 и 2015 гг., ОРС, \% и п.п.

\begin{tabular}{|c|c|c|c|c|}
\hline Возрастные групшы & 2000 r. & 2005 г. & 2010 г. & 2015 г. \\
\hline 15-19 лет & $7,6 \%$ & $5,6 \%$ & $2,8 \%$ & $1,5 \%$ \\
\hline 20-29 лет & $22,9 \%$ & $26,3 \%$ & $26 \%$ & $23,8 \%$ \\
\hline 30-39 лет & $25,4 \%$ & $24,7 \%$ & $25,3 \%$ & $27,2 \%$ \\
\hline 40-49 лет & $21,8 \%$ & $25,1 \%$ & $25 \%$ & $22,9 \%$ \\
\hline 50-59 лет & $9 \%$ & $11,7 \%$ & $16,2 \%$ & $19 \%$ \\
\hline 60 лет - 72 года & $13,3 \%$ & $6,6 \%$ & $4,6 \%$ & $5,6 \%$ \\
\hline \multicolumn{5}{|c|}{ Показатели динамики структуры занятости (п.п.) } \\
\hline 15-19 лет & & -2 п.п. & $-2,8$ п.п. & $-1,3$ п.п. \\
\hline 20-29 лет & & +3,4 п.п. & -0,3 п.п. & $-2,2$ п.п. \\
\hline 30-39 лет & & -0,7 п.п. & $+0,6$ п.п. & $+1,9$ п.п. \\
\hline 40-49 лет & & +3,3 п.п. & -0,1 п.п. & $-2,1$ п.п. \\
\hline 50-59 лет & & $+2,7$ п.п. & $+4,5$ п.п. & $+2,8$ п.п. \\
\hline 60 лет - 72 года & & -6,7 п.п. & -2 п.п. & +1 п.п. \\
\hline
\end{tabular}

Таблица Б. Уровни занятости в неформальном (НФС) и формальном (ФС) секторах в 2000, 2005, 2010 и 2015 гг., ОРС, \% от всех занятых в данной возрастной категории

\begin{tabular}{|c|c|c|c|c|c|}
\hline \multirow{2}{*}{$\begin{array}{l}\text { Тип занятости } \\
\text { на основной работе }\end{array}$} & \multicolumn{5}{|c|}{ Возрастные категории } \\
\hline & 20-29 лет & 30-39 лет & 40-49 лет & 50-59 лет & 60 лет -72 года \\
\hline \multicolumn{6}{|c|}{2000 г. } \\
\hline Занятые в НФС & 12,8 & 11,6 & 8,8 & 7,7 & 32,0 \\
\hline Занятые в ФС & 87,0 & 88,3 & 91,1 & 92,20 & 67,8 \\
\hline Неформально занятые в ФС & 0,2 & 0,1 & 0,1 & 0,1 & 0,2 \\
\hline \multicolumn{6}{|c|}{2005 г. } \\
\hline Занятые в НФС & 18,3 & 15,9 & 13,2 & 10,0 & 25,8 \\
\hline Занятые в ФС & 81,3 & 83,8 & 86,5 & 89,7 & 73,9 \\
\hline Неформально занятые в ФС & 0,4 & 0,3 & 0,3 & 0,3 & 0,3 \\
\hline \multicolumn{6}{|c|}{2010 г. } \\
\hline Занятые в НФС & 16,5 & 15,0 & 14,2 & 11,4 & 17,5 \\
\hline Занятые в ФС & 82,9 & 84,7 & 85,5 & 88,3 & 82,0 \\
\hline Неформально занятые в ФС & 0,7 & 0,3 & 0,3 & 0,2 & 0,5 \\
\hline \multicolumn{6}{|c|}{2015} \\
\hline Занятые в НФС & 20,8 & 19,0 & 18,2 & 16,0 & 20,6 \\
\hline Занятые в ФС & 78,6 & 80,6 & 81,6 & 83,8 & 78,8 \\
\hline Неформально занятые в ФС & 0,6 & 0,4 & 0,3 & 0,3 & 0,5 \\
\hline
\end{tabular}

Источник: расчеты автора. 
Таблица В. Уровни занятости в НФС и ФС в 2000, 2005, 2010 и 2015 гг., пятилетние возрастные интервалы, ОРС, \% от всех занятых в данной возрастной категории

\begin{tabular}{|c|c|c|c|c|c|c|c|c|c|c|}
\hline \multirow{2}{*}{$\begin{array}{l}\text { Тй } \\
\text { занятости } \\
\text { на основ- } \\
\text { ной работе }\end{array}$} & \multicolumn{10}{|c|}{ Возрастные категории } \\
\hline & $\begin{array}{l}20 \text { лет - } \\
24 \text { года }\end{array}$ & $\begin{array}{c}\text { 25-29 } \\
\text { лет }\end{array}$ & $\begin{array}{l}30 \text { лет - } \\
34 \text { года }\end{array}$ & $\begin{array}{c}\text { 35-39 } \\
\text { лет }\end{array}$ & $\begin{array}{l}40 \text { лет - } \\
44 \text { года }\end{array}$ & $\begin{array}{c}45-49 \\
\text { лет }\end{array}$ & $\begin{array}{l}50 \text { лет - } \\
54 \text { года }\end{array}$ & $\begin{array}{c}55-59 \\
\text { лет }\end{array}$ & $\begin{array}{c}60 \text { лет - } \\
64 \text { года }\end{array}$ & $\begin{array}{l}65 \text { лет - } \\
72 \text { года }\end{array}$ \\
\hline \multicolumn{11}{|c|}{2000 г. } \\
\hline $\begin{array}{l}\text { Занятые } \\
\text { в НФС }\end{array}$ & 13,5 & 12,3 & 11,7 & 11,4 & 9,6 & 7,9 & 6,2 & 11,1 & 24,6 & 47,5 \\
\hline $\begin{array}{l}\text { Занятые } \\
\text { в ФС }\end{array}$ & 86,2 & 87,6 & 88,1 & 88,5 & 90,3 & 92,0 & 93,7 & 88,8 & 75,2 & 52,2 \\
\hline $\begin{array}{l}\text { Неформаль- } \\
\text { но занятые } \\
\text { в ФС }\end{array}$ & 0,3 & 0,1 & 0,2 & 0,1 & 0,1 & 0,1 & 0,1 & 0,1 & 0,2 & 0,2 \\
\hline \multicolumn{11}{|c|}{2005 г. } \\
\hline $\begin{array}{l}\text { Занятые } \\
\text { в НФС }\end{array}$ & 20,8 & 16,4 & 15,7 & 16,0 & 14,3 & 12,2 & 10,4 & 9,2 & 19,8 & 33,4 \\
\hline $\begin{array}{l}\text { Занятые } \\
\text { в ФС }\end{array}$ & 78,6 & 83,4 & 84,0 & 83,6 & 85,4 & 87,5 & 89,4 & 90,5 & 80,0 & 66,2 \\
\hline $\begin{array}{l}\text { Неформаль- } \\
\text { но занятые } \\
\text { в ФС }\end{array}$ & 0,7 & 0,3 & 0,3 & 0,3 & 0,3 & 0,4 & 0,2 & 0,3 & 0,2 & 0,4 \\
\hline \multicolumn{11}{|c|}{2010 г. } \\
\hline $\begin{array}{l}\text { Занятые } \\
\text { в НФС }\end{array}$ & 18,3 & 15,2 & 15,2 & 14,8 & 14,9 & 13,6 & 11,7 & 11,0 & 12,8 & 26,2 \\
\hline $\begin{array}{l}\text { Занятые } \\
\text { в ФС }\end{array}$ & 80,9 & 84,3 & 84,5 & 84,9 & 84,8 & 86,1 & 88,0 & 88,8 & 86,7 & 73,2 \\
\hline $\begin{array}{l}\text { Неформаль- } \\
\text { но занятые } \\
\text { в ФС }\end{array}$ & 0,9 & 0,5 & 0,3 & 0,3 & 0,3 & 0,3 & 0,2 & 0,2 & 0,4 & 0,6 \\
\hline \multicolumn{11}{|c|}{2015 г. } \\
\hline $\begin{array}{l}\text { Занятые } \\
\text { в НФС }\end{array}$ & 23,9 & 19,2 & 19,2 & 18,8 & 18,4 & 18,0 & 16,3 & 15,4 & 17,9 & 29,3 \\
\hline $\begin{array}{l}\text { Занятые } \\
\text { в ФС }\end{array}$ & 75,2 & 80,3 & 80,4 & 80,8 & 81,3 & 81,8 & 83,4 & 84,3 & 81,7 & 70,0 \\
\hline $\begin{array}{l}\text { Неформаль- } \\
\text { но занятые } \\
\text { в ФС }\end{array}$ & 0,9 & 0,5 & 0,4 & 0,4 & 0,3 & 0,3 & 0,3 & 0,3 & 0,5 & 0,7 \\
\hline
\end{tabular}

Источник: расчеты автора. 


\title{
Older Workers in the Russian Informal Sector
}

\section{A. ZUDINA*}

\begin{abstract}
*Anna Zudina - PhD in Sociology, Researcher, Centre for Labour Market Studies, National Research University Higher School of Economics. Address: 20, Myasnitskaya St., Moscow, 101000, Russian Federation. E-mail: azudina@hse.ru
\end{abstract}

Citation: Zudina A. (2021) Older Workers in the Russian Informal Sector. Mir Rossii, vol. 30, no 2, pp. 72-97 (in Russian). DOI: 10.17323/1811-038X-2021-30-2-72-97

\begin{abstract}
Informal employment and employment in the informal sector are regarded as key types of vulnerable and unprotected labour in many countries. By definition, they are associated with the absence of formal employment contracts, and therefore represent one of the most important challenges for modern pension systems and social protection. The greatest risks of informal employment are among those representatives of the labour market who face restrictions in access to formal jobs, including older workers. This paper analyses the scale, dynamics and structure of employment in the informal sector of pre-retirement and retirement age workers, their socio-demographic characteristics along with the occupational and industrial features of their jobs, using the data of the Russian Labour Force Survey (LFS) of Rosstat for 2000, 2005, 2010 and 2015. The results indicate that by 2015, the Russian informal sector employed more than 3 million people over the age of 50, and that informality is most prevalent among older workers $(65+)$. There is also an increasing deformalization of the employment of workers aged 50-54, which may be explained by a deterioration in the prospects for job search and career advancement in 'early' preretirement ages in the Russian labour market. The most important characteristic of Russian informal employment is the increasing convergence of the educational and occupationalindustrial structure of workers of different ages. The main risks of informal employment among workers over 60 are shifting from the lowest levels of education (lower secondary or primary education) to technical college and upper secondary education. They are associated with the greatest risks of informality both in the primary working ages and among 50-59 year-old informal workers. In addition, older workers are employed in the same industries and occupations of the informal sector as younger representatives. This points to the 'universal' nature of labour demand in the informal sector, in which both young and older workers find jobs. The convergence of the structure of informal employment among workers of different ages, combined with the future entry into older ages of more numerous cohorts and the increasing deformalization of employment of 50-59 year olds, could lead to a further expansion of informality in the Russian labour market.
\end{abstract}

Keywords: older workers, informal sector, labour market, retirement, Russia, Labour Force Survey 


\section{References}

Alvarez C.V., Potes M. del P.E., Merchán M.E.P. (2016) Quality of Life and Informal Labor among Elderly Persons in an Intermediate Colombian City, 2012-2013. Revista Brasileira de Geriatria e Gerontologia, vol. 19, no 3, pp. 415-427.

Farber H.S. (2004) Job Loss in the United States, 1981-2001. Research in Labor Economics, vol. 23, pp. 69-117.

Gatti R., Angel-Urdinola D.F, Silva J., Bodor A. (2014) Striving for Better Jobs: The Challenge of Informality in the Middle East and North Africa. The World Bank. Directions in Development. No. 90271, Washington, DC.

Heywood J.S., Siebert W.S. (2009) Understanding the Labour Market for Older Workers: A Survey. IZA Discussion Paper Series. No. 4033.

ILO (2014). Informality and the Quality of Employment in G20 Countries. Report Prepared for the G20 Labour and Employment Ministerial Meeting Melbourne, Australia, 10-11 September 2014.

ILO (2018). Women and Men in the Informal Economy: A Statistical Picture (Third Edition). International Labour Office, Geneva: ILO.

Jütting J., Parlevliet J., Xenogiani T. (2008) Informal Employment Re-Loaded. OECD Developement Centre Working Paper. No. 266, Paris: OECD.

Kelly P. (2005) Integration and Participation of Older Persons in Development. UN Department of Economic and Social Affairs, UN Secretariat.

Lahey J.N. (2010) International Comparison of Age Discrimination Laws. Research on Aging, vol. 32, no 6, pp. 679-697.

Lukyanova A.L. (2012) Pensionnoe strakhovanie, neformal'naya zanyatost' $i$ samozanyatost' [Pension Insurance, Labor Market Informality and Self-employment]. Working Paper WP3/2012/02, Moscow: HSE.

Lukyanova A.L., Kapeliushnikov R.I. (2019) Rabotniki predpensionnogo i pensionnogo vozrasta na rossiyskom rynke truda: tendentsii v reallokatsii zanyatosti [Older Workers in the Russian Labor Market: Trends in Employment Reallocation]. Voprosy ekonomiki, no 11, pp. 5-34.

Maloney W.F. (1999) Does Informality Imply Segmentation in Urban Labor Markets? Evidence from Sectoral Transitions in Mexico. The World Bank Economic Review. No. 13, pp. 275-302.

McCaig B., Pavcnik N. (2015) Informal Employment in a Growing and Globalizing Low-income Country. American Economic Review: Papers and Proceedings, vol. 105, no 5, pp. 545-550.

Metodologicheskoe rukovodstvo dlya pol'zovatelej bazy mikrodannykh obsledovanij naseleniya po problemam zanyatosti [Methodological Guide to the Russian Labour Force Survey microdata] (2002), Moscow: Rosstat.

Mikkonen-Jeanneret E., Rayapova R., Yefimov N. (2011) Off the Grid: Exploring the Expanding Informal Economy and Threats to Old-age Social Protection in Kyrgyzstan and Tajikistan. Report by HelpAge International, Eastern Europe and Central Asia.

Murrugarra E. (2011) Employability and Productivity among Older Workers: A Policy Framework and Evidence from Latin America. Well-being and Social Policy, vol. 7, no 2, pp. 53-99.

OECD (2008). Declaring Work or Staying Underground: Informal Employment in Seven OECD Countries. Chapter 2 in OECD Employment Outlook, OECD, Paris, pp. 79-137.

Oude Mulders J., Wadensjö E. (2015) Domain: Labour Market. Understanding Employment Participation of Older Workers: Creating a Knowledge Base for Future Labour Market Challenges (eds. Hasselhorn H.M., Apt W.). Research Report. Federal Ministry of Labour and Social Affairs (BMAS) and Federal Institute for Occupational Safety and Health (BAuA). BMAS/ BAuA, Berlin, pp. 31-40.

Perron R. (2018) The Value of Experience: Age Discrimination against Older Workers Persists, Washington, DC: AARP.

Perry G.E., Maloney W.F., Arias O.S., Fajnzylber P., Mason A.D., Saavedra-Chanduvi J. (2007) Informality: Exit and Exclusion. Latin America and the Caribbean Studies Report, Washington, DC: The World Bank. 
Ponyatiya i opredeleniya [Concepts and Definitions] (2015). Obsledovanie naseleniya po problemam zanyatosti [Russian Labour Force Survey], Moscow: Rosstat, pp. 9-12. Available at: https://www.gks.ru/bgd/regl/b15_30/IssWWW.exe/Stg/d04/01-5.doc, assessed 20.02.2021.

Sahoo B., Neog B.G. (2015) Heterogeneity and Participation in Informal Employment among Non-cultivator Workers in India. MPRA Paper. No. 68136, University Library of Munich.

Sinyavskaya O.V. (2017) Rossiyskaya pensionnaya sistema v kontekste demograficheskikh vyzovov i ogranichenij [Russian Pension System in the Context of Demographic Challenges and Constraints]. HSE Economic Journal, vol. 21, no 4, pp. 562-591.

Sinyavskaya O.V., Biryukova S.S. (2018) Vozmozhnye mery snizheniya neformal'noj zanyatosti i skrytoj oplaty truda [Possible Measures Aimed at Reducing Informal Employment and Hidden Wages]. Journal of the New Economic Association, no 1, pp. 193-202.

Sonina Yu.V., Kolosnitsyna M.G. (2015) Pensionery na rossijskom rynke truda: tendentsii ekonomicheskoj aktivnosti lyudej pensionnogo vozrasta [Pensioners on the Russian Labour Market: Trends of Economic Activity in Pension Age]. Demographic Review, vol. 2, no 2, pp. 37-53.

Stuart E., Samman E., Hunt A. (2018) Informal Is the New Normal. Improving the Lives of Workers at Risk of Being Left Behind. Overseas Development Institute Working Paper Series. Working Paper. No. 530.

The World Bank (2009). Federative Republic of Brazil: Social Insurance and Labor Supply: Assessing Incentives and Redistribution. Human Development Sector Management Unit, Latin America and the Caribbean Region, The World Bank, Washington, DC.

Tondini A., Ardington C., Woolard I. (2017) Public Pensions and Elderly Informal Employment: Evidence from a Change in Retirement Age in South Africa. SALDRU. Working Paper. No. 206.

Vishnevskaya N.T. (2017) Rabotniki starshikh vozrastov na rynke truda v stranakh OESR [Older Workers in the OECD Labor Market]. HSE Economic Journal, vol. 21, no 4, pp. 680-701. 